Portland State University

PDXScholar

Environmental Science and Management

Faculty Publications and Presentations

Environmental Science and Management

$10-11-2013$

\title{
Carbon Dynamics in the Future Forest: the Importance of Long-Term Successional Legacy and Climate-Fire Interactions
}

\author{
E. Louise Loudermilk \\ Portland State University \\ Robert M. Scheller \\ Portland State University \\ Peter J. Weisberg \\ University of Nevada, Reno \\ Jian Yang \\ University of Nevada, Reno \\ Thomas E. Dilts \\ University of Nevada, Reno
}

Follow this and additional works at: https://pdxscholar.library.pdx.edu/esm_fac

PPreatopabe Forvadditionablauttionstors and Impact Assessment Commons, and the Forest Biology

Commons

Let us know how access to this document benefits you.

\section{Citation Details}

Loudermilk, E. L., Scheller, R. M., Weisberg, P. J., Yang, J., Dilts, T. E., Karam, S. L. and Skinner, C. (2013), Carbon dynamics in the future forest: the importance of long-term successional legacy and climate-fire interactions. Global Change Biology, 19: 3502-3515. doi: 10.1111/gcb.12310

This Article is brought to you for free and open access. It has been accepted for inclusion in Environmental Science and Management Faculty Publications and Presentations by an authorized administrator of PDXScholar. Please contact us if we can make this document more accessible: pdxscholar@pdx.edu. 


\section{Authors}

E. Louise Loudermilk, Robert M. Scheller, Peter J. Weisberg, Jian Yang, Thomas E. Dilts, Sarah L. Karam, and Carl Skinner

This article is available at PDXScholar: https://pdxscholar.library.pdx.edu/esm_fac/20 


\title{
Carbon dynamics in the future forest: the importance of long-term successional legacy and climate-fire interactions
}

\author{
E. LOUISE LOUDERMILK*, ROBERT M. SCHELLER*, PETER J. WEISBERG†, JIAN YANG†, \\ THOMAS E. DILTS $\uparrow$, SARAH L. KARAM† and CARL SKINNER \\ *Environmental Science and Management Department, Portland State University, PO Box 751, Portland, OR 97207, USA, \\ $\dagger$ Department of Natural Resources and Environmental Science, University of Nevada, Reno, 1664 N. Virginia St., Mail Stop 186, \\ Reno, Nevada 89557, USA, \$Pacific Southwest Research Station, USDA Forest Service, 3644 Avtech Parkway, Redding, CA \\ 96002, USA
}

\begin{abstract}
Understanding how climate change may influence forest carbon (C) budgets requires knowledge of forest growth relationships with regional climate, long-term forest succession, and past and future disturbances, such as wildfires and timber harvesting events. We used a landscape-scale model of forest succession, wildfire, and C dynamics (LANDIS-II) to evaluate the effects of a changing climate (A2 and B1 IPCC emissions; Geophysical Fluid Dynamics Laboratory General Circulation Models) on total forest C, tree species composition, and wildfire dynamics in the Lake Tahoe Basin, California, and Nevada. The independent effects of temperature and precipitation were assessed within and among climate models. Results highlight the importance of modeling forest succession and stand development processes at the landscape scale for understanding the $\mathrm{C}$ cycle. Due primarily to landscape legacy effects of historic logging of the Comstock Era in the late 1880s, C sequestration may continue throughout the current century, and the forest will remain a $\mathrm{C}$ sink (Net Ecosystem Carbon Balance $>0$ ), regardless of climate regime. Climate change caused increases in temperatures limited simulated $C$ sequestration potential because of augmented fire activity and reduced establishment ability of subalpine and upper montane trees. Higher temperatures influenced forest response more than reduced precipitation. As the forest reached its potential steady state, the forest could become $\mathrm{C}$ neutral or a $\mathrm{C}$ source, and climate change could accelerate this transition. The future of forest ecosystem $\mathrm{C}$ cycling in many forested systems worldwide may depend more on major disturbances and landscape legacies related to land use than on projected climate change alone.
\end{abstract}

Keywords: carbon, climate change, fire, LANDIS-II, landscape legacy, model, net ecosystem carbon balance, soil

Received 22 October 2012 and accepted 21 May 2013

\section{Introduction}

Understanding the effects that climate change may have on forest carbon $(C)$ budgets requires knowledge of regional climate effects on forest growth, long-term forest succession, and important past and future disturbances (Westerling et al., 2006; Millar et al., 2007; Xu et al., 2009). Climate change will affect forests through the physiological response of trees to future climate variability, including altered trends in mortality and productivity, and subsequent changes in forest succession. Changes in forest composition and structure will be altered by climate-induced changes in natural

Present address: E. Louise Loudermilk, Forestry Sciences Laboratory, Center for Forest Disturbance Science, USDA Forest Service, 320 Green Street,

Athens, GA 30602, USA

Correspondence: E. Louise Loudermilk, tel. +706 559 4309, fax +706 559 4245, e-mail: elloudermilk@fs.fed.us disturbances regimes (e.g., frequency and duration of wildfires, Dale et al., 2001). Climate change effects are often region specific, whereby plant species and ecosystem processes (e.g., nutrient cycling, disturbances) may behave idiosyncratically (Scheller \& Mladenoff, 2005, 2008). The coupled effects from past disturbances (e.g., historic logging), large wildfires, and future changes in climate call for a flexible modeling approach that can incorporate sufficient interaction, contingency, and site specificity; and be implemented in many forested systems (e.g., Scheller et al., 2007, 2011b).

Changes in regional weather and climatic patterns will determine the physiological response of trees. In California, a $2-5{ }^{\circ} \mathrm{C}$ increase in mean annual temperature is expected to affect the spatial distribution and phenology of extant tree species (Millar et al., 2006). Magnitude and seasonal distribution shifts in precipitation will vary among regions and depend on local weather patterns. In the western US, increasing temperatures and decreasing precipitation have been identified 
as a significant cause of increasing tree mortality (Van Mantgem et al., 2009). Climate projections for California, suggest little change in annual total precipitation, although there are discrepancies among models (Lenihan et al., 2003). The projected alterations in temperature or precipitation, independently or in conjunction, may affect various ecosystem processes. Increased temperature may reduce long-term soil moisture, with subsequent effects on decomposition rates and nitrogen availability, reducing forest productivity (Kirschbaum, 1995; Lenihan et al., 2003). In the Lake Tahoe Basin (LTB) (study area of this research, CA, NV), mean annual temperatures are expected to increase by $1-5{ }^{\circ} \mathrm{C}$ throughout the 21 st century, whereas projected precipitation is variable (Coats et al., 2010). Throughout the Sierra Nevada, changing climate conditions are expected to reduce snow pack with more precipitation falling as rain, earlier snow melt, and prolonged droughty summers (Battles et al., 2008).

A warmer climate will likely alter the net $C$ balance of many forested landscapes. Northern hemisphere C uptake estimates in the 1990s vary between 0.3 and $0.9 \mathrm{Pg} \mathrm{C} \mathrm{yr}^{-1}$ (Goodale et al., 2002). This C uptake is largely in northern forests (Goodale et al., 2002; Houghton, 2003b) and is likely due to fire suppression, regrowth from extensive harvesting over the past two centuries, and increased nitrogen deposition and atmospheric C fertilization (Schafer et al. 2003). The magnitude and duration of continued $C$ uptake is uncertain, especially at the local scale at which forest management occurs, and may decline if drier conditions reduce growth rates (Goodale et al., 2002; Houghton, 2003b; Albani et al., 2006). Methodological difficulties in quantifying the $\mathrm{C}$ balance and managing for $\mathrm{C}$ emissions (Galik \& Jackson, 2009) are major obstacles in determining how individual forests fit into $\mathrm{C}$ offset programs (Higgins et al., 2001). Using a modeling approach, such as LANDIS-II, overcomes these difficulties by projecting changes in forest $\mathrm{C}$ flux in response to various disturbances (e.g., Scheller et al., 2011a, b).

Climate change may have dramatic impacts on wildfire regimes as well (McKenzie et al., 2004). In the western US, increasing temperatures advance the timing of snow melt and vegetation green up, dry fuels earlier, and extend wildfire seasons. This climate variability has been the predominant cause of recent increases in fire activity in the west, despite the rise in fuel accumulation (Littell et al., 2009). Relative to the total period of fire suppression, the total area burned in US. National Forests has recently increased because of these climate-fire interactions (Westerling et al., 2006). Wildfire frequencies are also expected to increase, causing a higher flux of greenhouse gas emissions (Campbell et al., 2007), and affecting forest C pools in significant, but unknown ways (Westerling et al., 2006).
Our objective was to evaluate the emergent responses of multiple interacting processes, namely climate change and wildfire activity, on total forest $C$ dynamics, within the regional landscape of the LTB, CA, and NV. We used two future $\mathrm{C}$ emissions scenarios as expressed within the Geophysical Fluid Dynamics Laboratory General Circulation Model, in combination with a landscape-scale model of forest succession (Scheller et al., 2007), wildfire (Sturtevant et al., 2009), and C dynamics (Scheller et al., 2011a). We examined forest C sequestration potential and net $\mathrm{C}$ emissions, as they relate to (i) landscape disturbance history and (ii) future changes in climate and wildfire activity. We assessed the independent effects of temperature and precipitation variability within and among emissions scenarios, as well as climate-fire interactions.

\section{Materials and methods}

\section{Study area}

Our study area comprises ca. 85000 ha of forested land in the Lake Tahoe Basin (LTB, Fig. 1). The climate is Mediterranean with a summer drought period. The basin-like topography and elevation range (ca. 1897-3320 m) control local temperature and precipitation patterns. Current mean daily temperatures range from -6 to $24^{\circ} \mathrm{C}$ and have an annual average temperature of $5{ }^{\circ} \mathrm{C}$. Snowfall is the primary form of precipitation (50-150 cm annually), which occurs mainly between October and May, and snowpack persists into the summer at higher elevations. Soils are classified as shallow Entisols or Inceptisols, and the more developed soils are Alfisols. The substrate is mainly granite with ancient volcanic bedrock lining the north shore (Rogers, 1974).

The forests of the LTB were once dominated by fire tolerant, shade-intolerant tree species (e.g., Jeffrey pine (Pinus jeffreyi), sugar pine ( $P$. lambertiana), and to a lesser extent subalpine and upper montane tree species (e.g., whitebark pine ( $P$. albicaulis), western white pine ( $P$. monticola), lodgepole pine (P. contorta)). Much of the forest was old-growth (Barbour et al., 2002; Nagel \& Taylor, 2005). During the Comstock Era logging of the late 19th century, timber harvested from the LTB was used for shoring up nearby mineshafts, creating timber flumes, and extending rail lines to nearby Virginia City, NV. By the turn of the century, $60 \%$ of the LTB had been clearcut and left to self-regenerate. The age and size distributions of the forest have since shifted to a dense forest of young and mature age cohorts $(<120$-year old). Fire suppression practices of the 1900s have exacerbated this shift and allowed more surface and ladder forest fuels to accumulate (Beaty \& Taylor, 2008) and shade tolerant trees (e.g., white fir, Abies concolor) to proliferate (Nagel \& Taylor, 2005).

\section{Model development, parameterization, \& calibration}

To address the disturbance feedbacks of climate change and wildfires on regional-scale forest and C dynamics (Fig. 2), we 


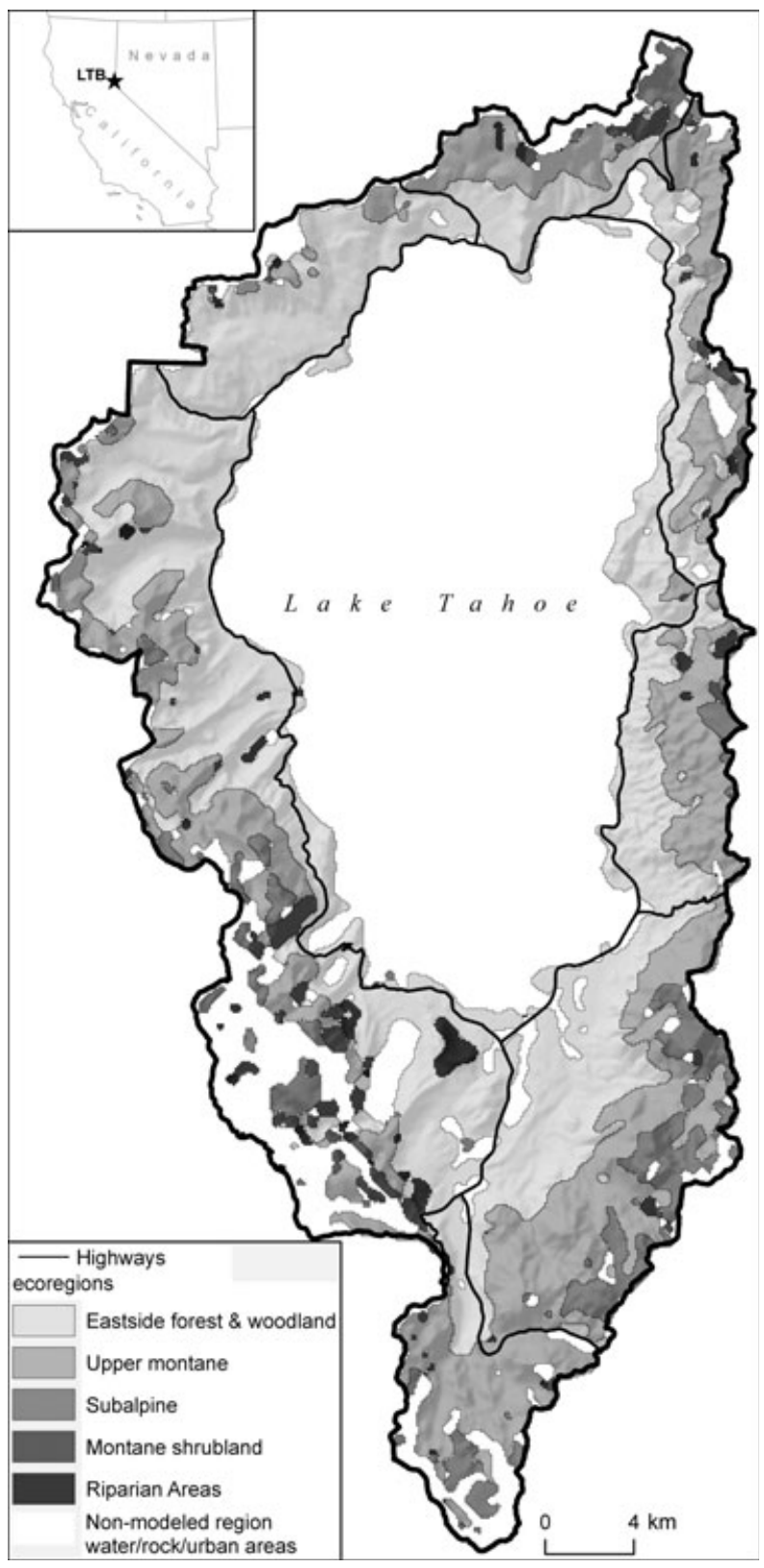

Fig. 1 Map of the study area for this research; the Lake Tahoe Basin, CA and NV, USA, including modeled ecoregions used in LANDIS-II simulations: Eastside forest and woodland (34 346 ha), upper montane (21 854 ha), subalpine (6292 ha), montane shrubland (3541 ha), and riparian areas (3017 ha).

used the Landscape Disturbance and Succession model, LANDIS-II (v.6.0). The LANDIS-II model has been used throughout the US. (Scheller et al., 2011a, b) and elsewhere (Cantarello et al., 2011; Steenberg et al., 2011) for landscape climate change research (Scheller \& Mladenoff, 2008; Xu et al., 2009). LANDIS-II offers the flexibility to integrate various ecosystem processes and disturbances that interact across large spatial extents and long time periods, ideal for projecting forest succession and responses to climatic variability.
Century extension. Ecosystem C dynamics were modeled using the LANDIS-II Century Succession extension (Scheller et al., 2011a), which is based on the original CENTURY soil model (Parton et al., 1983). This extension (hereon called 'Century') integrates aboveground processes of stand dynamics with $C$ and nitrogen cycling as well as decomposition and accumulation of soil C. C pools are described in 'Landscape simulations \& analysis'. Pool flows and interactions with climate (e.g., effects from temperature and changes in soil moisture), as well as further parameter descriptions and examples of calibration procedures for Century, are found elsewhere (Scheller et al., 2011a, b), including the Century User's Guide (http://www.landis-ii.org/exts/Century-succession).

Century parameters were developed for three ecosystem levels: tree species, functional groups, and ecoregions (Tables S1-S5). Growth response, modeled at the species and functional group level, was dependent on ecoregion-level soil and climate characteristics. Minimum January temperature, growing degree days, and maximum drought index determined species level establishment ability, which was calculated every time step. The vegetation within the LTB is well adapted to the droughty summer months and benefits mainly from the spring snow melt and early autumn rainfall. As such, the functional groups were parameterized to allow productivity (hence, minimal water and soil moisture limitations) during the dry summer months. Temperature sensitivity, e.g., Fig. S1, was similar to a previous study within the Sierra Nevada (Syphard et al., 2011), with details in Tables S1-S5. Net primary production (NPP) temperature optimum was $23{ }^{\circ} \mathrm{C}$ for all functional groups (Table S2, see PPDF1 Century parameter). Soil temperature, influencing decomposition and plant growth, was a function of maximum and minimum air temperature and canopy biomass. Soil decay was a function of water and temperature. Temperature and soil moisture effects on decomposition followed the equations from CENTURY (Parton et al., 1983, 1994).

Six target model outputs were chosen to calibrate and validate Century parameters based on available literature and expert opinion. These include aboveground net primary productivity (ANPP), NPP, net ecosystem production (NEP), aboveground live biomass, soil organic $\mathrm{C}$ (SOC), and soil inorganic nitrogen (Mineral N). For consistency, the base climate was used during these simulations. ANPP was calibrated by comparing simulated mean annual ANPP values against measured values of annual ANPP in a nearby 50-year-old ponderosa pine plantation (Campbell et al., 2009), a species closely related taxonomically to Jeffrey pine (Critchfield \& Little, 1966). A single site consisting of one young (5-year old) age cohort of Jeffrey pine was used to initialize the simulation and five replicates were run to year 45 (50-year-old stand). Simulations resulted in mean annual ANPP of $464(\mathrm{SD}=55) \mathrm{g}$ $\mathrm{C} \mathrm{m}^{-2} \mathrm{yr}^{-1}$, similar to the reference site $(435, \mathrm{SD}=69, \mathrm{~g}$ $\mathrm{C} \mathrm{m}^{-2} \mathrm{yr}^{-1}$ ) and comparable to general estimates for temperate biomes (456 $\mathrm{g} \mathrm{C} \mathrm{m}^{-2} \mathrm{yr}^{-1}$; Chapin et al., 2002). Using the same conditions, the simulated monthly fluctuations in NPP and NEP were compared to the Ameriflux site (Blodgett Forest, CA, USA, http://ameriflux.ornl.gov/) within the same reference site. From the Ameriflux data, maximum NPP and 


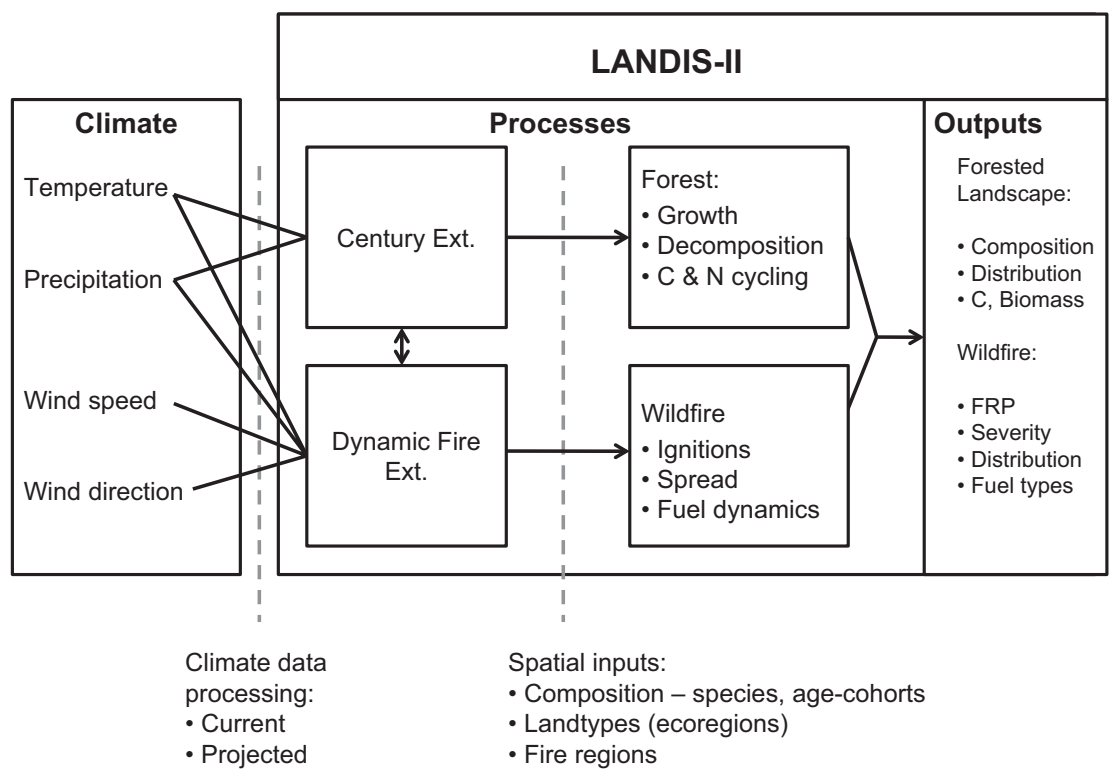

Fig. 2 LANDIS-II climate inputs and processes modeled for the forested landscape of the Lake Tahoe Basin. Climate data were implemented into the Century extension and Dynamic Fire extension using monthly and seasonal (daily) inputs, respectively, of current and projected climate (years 2010-2110). Processes in the Century extension include above and belowground components (e.g., plant root, shoot, and leaf biomass, soil organic matter). FRP, fire rotation period.

minimum NEP (summer months) ranged from about 100 to 200 and 75 to $150 \mathrm{~g} \mathrm{C} \mathrm{m}^{-2}$ month $^{-1}$, respectively, while our simulations ranged from about 100 to 150 and 50 to $125 \mathrm{~g} \mathrm{C} \mathrm{m}^{-2}$ month $^{-1}$, respectively. Our initial aboveground live biomass was validated against a separate remote sensing data set developed for the LTB (Dobrowski et al., 2005). Mean simulated and measured aboveground live biomass across the LTB was 10006 and $10787 \mathrm{~g} \mathrm{~m}^{-2}$, respectively. In Century, there are three SOC pools: fast, slow, and passive. Decay rates of the three SOC pools were calibrated to a consistent SOC decay, such that the decay rate of SOM2 (the slow pool) had the largest control over total SOC. A range of decay rate constants for SOM2 $\left(0.01,0.02,0.03,0.04 \mathrm{yr}^{-1}\right)$ were explored. A decay rate of $0.02 \mathrm{yr}^{-1}$ for SOM2 produced accurate initial conditions [as compared to Zinke et al., 1998; 3950 (SD = 532) $\mathrm{g} \mathrm{C} \mathrm{m}^{-2}$ ] and a realistic SOC accumulation rate (Fig. S2). Simulated mineral $\mathrm{N}$ values (mean (SD) across 100 years: 4.3 (0.6) $\mathrm{g} \mathrm{N} \mathrm{m}^{-2}$ ) were comparable to target mineral $\mathrm{N}$ estimates (5-10 $\mathrm{g} \mathrm{N} \mathrm{m}^{-2}$ ) from local expert opinion (S. Karam \& D. Johnson, Personal communications) and similar to another study (Miller et al., 2010).

Dynamic fire extension. The Dynamic Fire and Fuels extension (hereon called 'Dynamic Fire') simulates fire behavior and fire effects based on a parameterized fire regime and forest fuel types as well as input fire weather and topography (Sturtevant et al., 2009). The LTB was divided into three fire regions, representing distinct fire regime characteristics, and associated with varying elevation, climate, and ignition density estimations. Each fire region had unique characteristics associated with ignitions and fire weather that influenced fire ignition and spread. Details on fire region classification and parameters are found in Table S6 and in (Loudermilk et al., 2012).
For wildfire calibration, we used local wildfire data and contemporary (base) climate, following procedures from Sturtevant et al. (2009). Target fire size distribution and occurrence were developed from Pacific Southwest Region 5 USDA forest service fire data (http://www.fs.usda.gov/ main/r5/landmanagement/gis). To represent the contemporary fire regime, only the latest 13 years of data (1995-2007) were used to develop our target values. This includes information on recent large wildfires, e.g., Angora (1250 ha). Although the fire database dates back to 1915, the fires recorded were typically small, infrequent (due to fire suppression efforts), and not representative of current forest conditions and fire activity. As such, fire ignitions were calibrated (Table S6) to simulate the low number of fires $>0.01$ ha found at the LTB during the contemporary fire record. The simulated fire size distribution was calibrated to these records (Fig. 3). The resulting fire rotation period (FRP) over five 100-year simulations was $360(\mathrm{SD}=12)$ years. This estimate was reasonable as compared with the recorded estimate of 476 years, given the short term reference data set as well as the recent rise in wildfire activity (Westerling et al., 2006; Safford et al., 2009) that will likely continue (McKenzie et al., 2004; Running, 2006). Furthermore, wildfire activity was markedly higher prior to 1880 than these calibrated values (Beaty \& Taylor, 2008). Therefore, 360 years is likely a conservative estimate of future FRP under no climate change. The forest was classified into fuel types similar to those created for the southern Sierra Nevada (i.e., Syphard et al., 2011). These fuel types represented fuel characteristics that drive fire spread rates and affect subsequent fire severity (Sturtevant et al., 2009; Syphard et al., 2011). Fuel types were reclassified every time step to account for changes in forest composition and age structure (e.g., growth, mortality). 


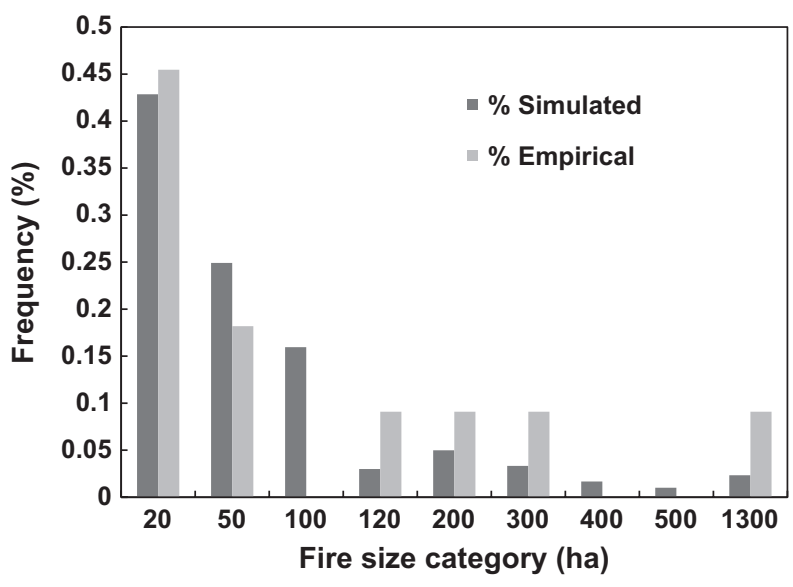

Fig. 3 Fire size distribution simulated using LANDIS-II (100 years, using base climate) and empirical data (1995-2007) from the study area.

Landscape $\mathcal{E}$ forest composition development. For our initial forest communities input map, we used the current vegetation map developed for the LTB by the Fuel Characteristic Classification System (FCCS, http://www.fs.fed.us/psw/partner ships/tahoescience/fccs.shtml) and the existing vegetation map (CALVEG) from the GIS Clearinghouse of the US Forest Service Pacific Southwest Region (http://www.fs.fed.us/r5/ rsl/clearinghouse/aa-ref-tmu.shtml). The FCCS database provided age-cohort information on trees and shrubs within the overstory, midstory, and understory at the LTB (Ottmar \& Safford, 2011). We used the 11 most abundant tree species found within the LTB (Table 1). Shrubs were grouped into four functional groups: nonnitrogen fixing resprouters, nonnitrogen fixing obligate seeders, nitrogen fixing resprouters, and nitrogen fixing obligate seeders. The resulting forest community map was coupled with Forest Inventory Analysis data from the LTB and nearby forests to provide detailed estimates of tree species composition and age cohorts that were distributed among forest types (e.g., mixed conifer), similar to (Syphard et al., 2011). This map was refined to account for the largest and most significant wildfires from years 2002 to 2010, where fire severity was high (e.g., Safford et al., 2009).

\section{Emissions scenarios \& implementation}

LANDIS-II has been used extensively for modeling climate change impacts across various forested landscapes ( $\mathrm{Xu}$ et al., 2007, 2009; Scheller \& Mladenoff, 2008). Climate is used uniquely depending on the extension. Within the Century extension, climate determines monthly tree growth, decomposition rates, and establishment capability. For the Dynamic Fire extension (Sturtevant et al., 2009), climate determines the seasonal distributions of fire weather and fuel conditions (e.g., fine fuel moisture, fuel availability) and incorporates the effects of extended drought periods (longer summers) and altered snow or precipitation patterns.

Study site climate projections were processed using existing downscaled Geophysical Fluid Dynamics Laboratory (GFDL)
General Circulation Models (GCM) of high (A2) and moderate (B1) global $\mathrm{CO}_{2}$ emissions scenarios of climate up to year 2100, specific to the LTB (Coats et al., 2010). These downscaled daily precipitation and temperature values $\left(12 \mathrm{~km}^{2}\right)$ were further processed using PRISM data (Parameter-elevation Regressions on Independent Slopes Model, http://www. prism.oregonstate.edu/, PRISM 30-year Normals (1971-2000), $800 \mathrm{~m}^{2}$ ) to provide area-weighted averages across each fire region and ecoregion.

Projected climate inputs used for the Century extension (unique by ecoregion) included monthly average minimum and maximum temperature $\left({ }^{\circ} \mathrm{C}\right)$, SD of mean temperature, total precipitation $(\mathrm{cm})$, and $\mathrm{SD}$ of precipitation. For the Dynamic Fire extension, seasonal (daily) fire weather variables, namely daily wind speed velocity $\left(\mathrm{km} \mathrm{h}^{-1}\right)$, wind direction (degrees), fine fuel moisture code (FFMC) (unitless), build-up index (unitless), fire weather class, and burn season (i.e., spring, summer, fall) were developed from daily projected climate values, including minimum and maximum temperature $\left({ }^{\circ} \mathrm{C}\right)$, total precipitation $(\mathrm{cm})$, and wind speed (Coats et al., 2010). Daily wind direction was obtained from a local weather station (SNOTEL site, Squaw Valley, CA, USA, http:/ / www.wcc.nrcs.usda.gov/nwcc/site? sitenum $=784$ \& state $=c a)$ and used for all climate simulations. FFMC and build-up index are derived from the Canadian Forest Fire Weather Index System (Van Wagner 1987), with details found in Sturtevant et al. (2009). For the Century and Dynamic Fire extensions, the climate variables were updated every 5 years (e.g., 2020-2024) for each emissions scenario, and influenced monthly growth, decomposition, establishment ability as well as seasonal fire weather, respectively, within each 5 -year-time step. For consistency, the first 5-year interval of B1 climate data was used to represent a continuation of the current climate.

\section{Landscape simulations $\mathcal{E}$ analysis}

Two approaches were used to assess how climate change would affect long-term forest change. The first approach consisted of simulating each climate scenario (A2, B1, base climate) separately for 100 years (2010-2110). The landscape was simulated at a 1 ha spatial resolution, and each scenario was replicated five times to account for climate, wildfire, and regeneration variability among replicates. We evaluated changes in forest productivity (ANPP), net ecosystem $\mathrm{C}$ balance (NECB), and above and below ground $\mathrm{C}$ allocation over time as well as species response to climate change. NECB is defined as the net rate of $\mathrm{C}$ accumulation by the ecosystem, i.e., NPP, minus heterotrophic respiration minus leaching minus disturbance (Chapin et al., 2002). Disturbance in this study was from wildfires. Live $\mathrm{C}$ included above and below ground live $\mathrm{C}$ (bole, leaves, fine and coarse roots). Detrital C included dead wood (bole and branches combined and coarse roots), leaf litter, and dead fine roots. SOC included the fast, slow, and passive pools and soil structural and metabolic components within $1 \mathrm{~m}$ soil depth. Total $\mathrm{C}$ included all $\mathrm{C}$ stored in the system (Live C + Detrital C + SOC). 


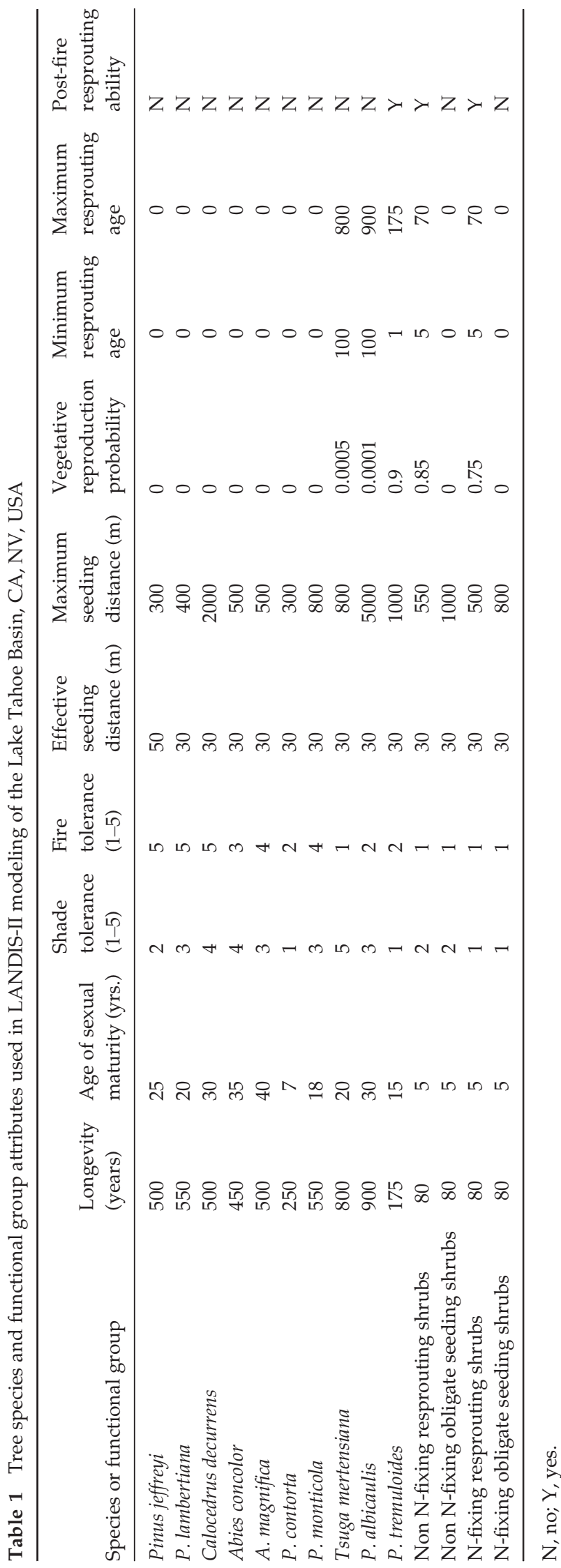

The second approach explored how projected changes in temperature and precipitation independently influenced $\mathrm{C}$ pools and fluxes. For this analysis, temperature or precipitation values from the A2 climate scenarios were replaced with the values from the base climate scenario, creating two new climate scenarios: a) 'A2 temperature only': A2 temperature with base precipitation, and b) 'A2 precipitation only': A2 precipitation with base temperature. All other parameters, extensions, and input files were identical to the first approach. Furthermore, simulations without fire were run to isolate the effects of climate-enhanced fire activity from climate change effects alone.

\section{Results}

\section{Climate change impacts on $C$ dynamics}

Both downscaled climate scenarios illustrated a clear trend of increasing temperature in the LTB (Fig. 4), with divergence between A2 and B1 emissions scenarios by midcentury. Mean annual temperature at the LTB at year 2110 was 5.2, 7.3, and $9.8^{\circ} \mathrm{C}$ for the base, $\mathrm{B} 1$, and A2 climate, respectively. The projected climate change scenarios (A2, B1) simulated ca. $22 \%$ less precipitation overall compared with the base climate scenario (Fig. 4), with no distinct differences in precipitation between $\mathrm{A} 2$ and $\mathrm{B} 1$. The simulated A2 and B1 climate followed similar temperature and precipitation trends as the original projected climate data from the LTB (Coats et al., 2010).

For our first approach (A2 vs. B1 vs. base climate), our simulations illustrated continued forest growth and $\mathrm{C}$ storage into the next century, regardless of changes in climate (Figs 5 and 6). As the forest continues to age for the next 100 years, simulated live and dead $\mathrm{C}$ pools more than doubled in mass (Fig. 5) under contemporary climate conditions. With increased temperatures of the A2 climate, higher mortality and lower forest productivity ( $-20 \%$, Fig. 6) reduced overall simulated C storage potential by $15 \%$ by year 2110 (Fig. 5, total C, A2 vs. Base Climate, Table S7).

Net ecosystem $C$ balance consistently remained highest for the base climate scenario, but was variable through time. NECB for A2 was half that of base climate at year 2110, but the system as a whole remained a $C$ sink throughout all simulations (NECB > 0, Fig. 6). As such, reduced productivity (ANPP), higher C flux from the system (e.g., wildfires, heterotrophic respiration), and reduced rate of $\mathrm{C}$ storage (in all $\mathrm{C}$ pools) from higher temperatures was most evident for the $\mathrm{A} 2$ scenario, where temperatures clearly diverged during the latter half of the century (year > 2060, Fig. 4). Although temperature differences were seen for the B1 climate scenario $\left(2.1^{\circ} \mathrm{C}\right.$ higher than base climate by 2110), overall forest growth (ANPP) and heterotrophic 

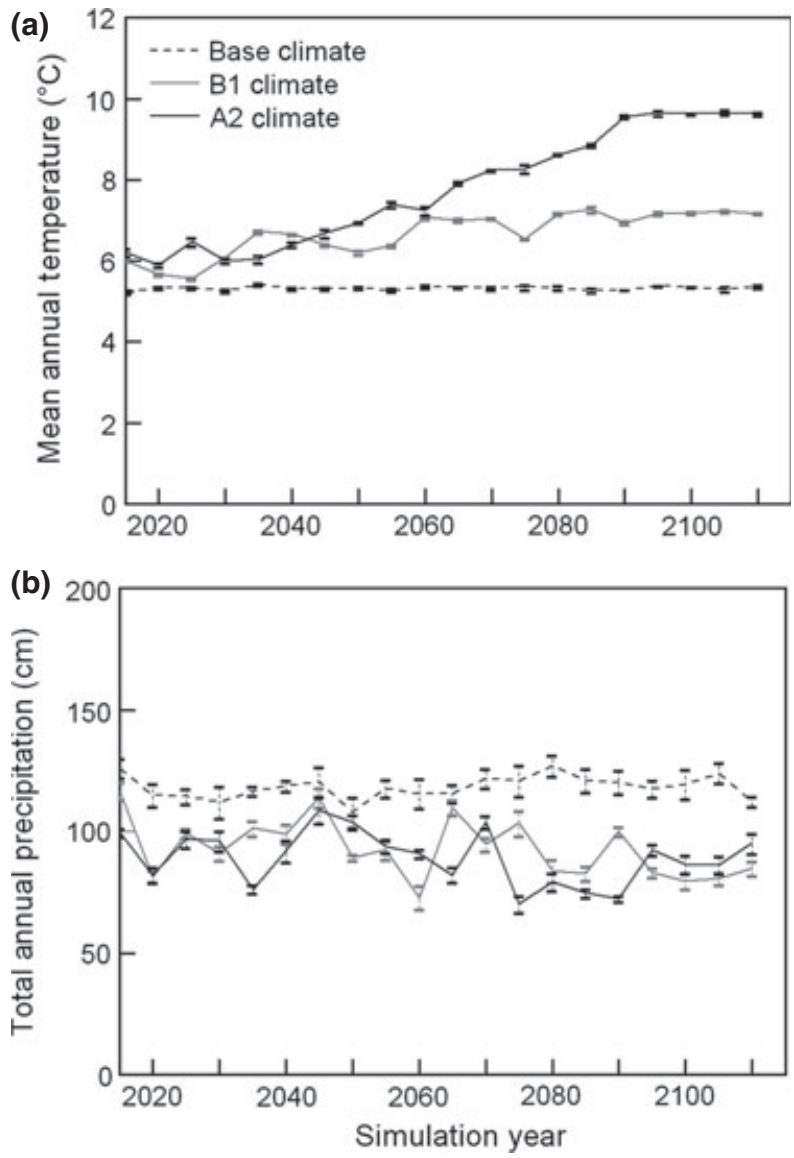

Fig. 4 (a) Mean annual temperature $\left({ }^{\circ} \mathrm{C}\right.$ ) and (b) total annual precipitation $(\mathrm{cm})(\mathrm{b})$ simulated at the Lake Tahoe Basin using current climate conditions and two Geophysical Fluid Dynamics Laboratory General Circulation Models of high (A2) and low (B1) emissions across 100 years. This represents landscape-level mean and SEs across five replicates.

respiration were minimally affected by this increase (Fig. 6). There was little difference among all live and dead C pools simulated by B1 and base climate (Fig. 5). As such, we focus here on comparisons between A2 and base climate scenarios.

Live C (bole, leaves, roots) accounted for ca. $65 \%$ of the total C on the LTB landscape, and followed the same trend in accumulation as total $\mathrm{C}$, with $17 \%$ reduced $C$ storage potential by year 2110 under A2 (Fig. 5a). Detrital C accounted for ca. 5\% of the total C, with a $14 \%$ lower value by 2110 (Fig. 5c). Detrital C pools were low compared with empirical estimates (e.g., Campbell et al., 2009; North \& Hurteau, 2011) due to overestimates of wood decay. Year-to-year variability in the detrital pool was because of the variability in fire, age-related tree mortality, and leaf senescence. SOC accounted for about 35\% of the total C. Differences among simulations of SOC across emissions scenarios were smaller than differences among simulations of other $\mathrm{C}$ pools, and did not diverge until later in the century (2075-2080, Fig. 5d). SOC was 6\% lower for A2 climate compared with base climate by 2110 .

Species-specific responses to climate change altered simulated C pools, as mediated by growth rate and establishment ability, with subsequent effects on forest successional trajectories. Besides wildfires, the reduced establishment ability of the subalpine and upper montane community was the largest effect of climate change on species dynamics. See more details in Table S8.

Our second approach, where temperature and precipitation effects were independently examined, demonstrated that increased temperatures (A2 climate) had the largest influence on forest growth, NECB, and $\mathrm{C}$ storage potential in all $\mathrm{C}$ pools (Fig. 7). Changes in precipitation had little effect among scenarios and may result from temperature influence on long-term soil moisture. Precipitation variability influenced annual fluctuations of ANPP, respiration (affecting NECB), detrital C, and annual wildfires (see next section). Total $\mathrm{C}$ and live $\mathrm{C}$ (Fig. 7a) demonstrated the clearest trends. Increasing temperature had a substantial negative effect on live $\mathrm{C}$ over time, whereas lower precipitation (with base climate temperature) had a slightly positive effect that occurred in the last few decades. The indirect influence on wildfires determined these discrepancies. ANPP (Fig. 7b) was dominantly driven by temperature, although intra-annual fluctuations were driven by a response to precipitation (i.e., A2 climate). Despite the year-to-year variability, the overall trend between A2 Temp only and A2 climate was virtually identical (Fig. 7). NECB, SOC, and detrital C followed a similar response (data not shown).

\section{Climate change and wildfire dynamics}

For our first approach (A2 vs. B1 vs. base climate), results revealed increasing wildfire size and decreasing FRP with increasing $C$ emissions (base, B1, A2; mean (SD) FRP: 360 (12), 338 (30), 293 (19) years, respectively, Fig. S3). The A2 climate resulted in a significantly larger mean and maximum area burned (across 100 years) than base climate and B1 climate $(P<0.01)$, as well as more variability in fire sizes (for A2 vs. base climate only, $P=0.02)$. Area burned was not different between B1 climate and base climate $(P>0.29)$. Mean annual area burned remained below $1 \%$ of total area for all climate scenarios. Even the largest fire (under A2 climate), 2600 ha (more than double the Angora fire: 1250 ha) was still less than $4 \%$ of the forested area. Fire sizes were larger with climate change due to more fire spread potential, but number of fires was restricted to calibrated values and was not different among climate scenarios. 
(a)
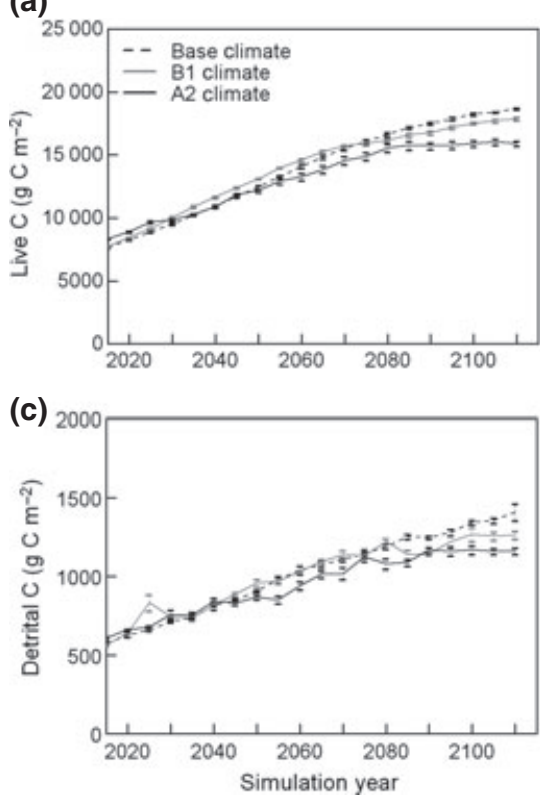

(b)

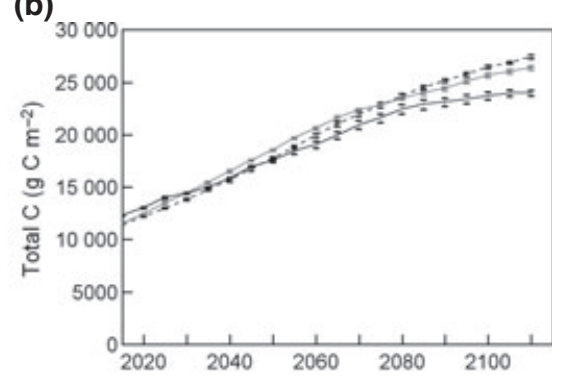

(d)

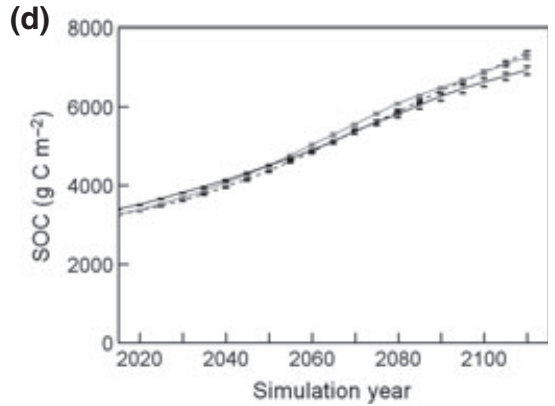

Fig. 5 Simulated mean landscape C estimates of (a) live C (bole, leaves, roots), (b) total C [live C + detrital C+SOC (soil organic C)], (c) detrital C, (d) SOC (3 soil pools: slow, fast, passive) simulated over 100 years (five replicates) using contemporary (base) climate and two emissions scenarios (A2, B1).

The results of LTB fire dynamics were twofold: First, simulated wildfires substantially reduced $C$ storage potential, regardless of climate scenario. Second, projected climate change effects on fire dynamics accelerated the impacts of climate change on forest $\mathrm{C}$ dynamics. Although a relatively small portion $(<1 \%)$ of area was burned annually, fire had a considerable effect on forest $C$ dynamics. For example, there was a $30-40 \%$ discrepancy of $\mathrm{C}$ storage potential among simulations with and without fire, regardless of climate scenario (e.g., live C, Fig. 8). The cumulative effects of small fires over time determined landscape-level mortality patterns. The higher combustion rate of dead and live fuels slowed the rate of $C$ sequestration in all $C$ pools. It is important to note that simulating this system without fire was entirely experimental and not representative of an ecosystem where wildfires are an inherent and inevitable disturbance.

The influence of climate change on fire weather and fuel conditions increased mean annual area burned (by $43 \%$, A2 climate) compared with contemporary climate. More area burned (Fig. S3), coupled with reduced establishment ability (Table S8), reduced landscapescale ANPP and rate of forest $C$ storage in all pools. When fire was removed from the system, there were small dissimilarities of aboveground $\mathrm{C}$ among scenarios before year 2080, when the effects of reduced establishment and lower heterotrophic respiration began to take effect.
In our second approach, we found that changes in temperature and precipitation ultimately shaped fire weather (Sturtevant et al., 2009) in the LTB through seasonal fluctuations of the FFMC, the Build-up-Index (BUI), and increasing the fire season length (by $25 \%$ by the year 2110). A 3\% increase (from base to A2 climate) in FFMC (i.e., ignition potential of fine fuels) by year 2110 was entirely driven by increased temperature. Changes in precipitation had no effect on FFMC. By 2110 , a $28 \%$ increase (from base to A2 climate) in BUI amount of fuel available for combustion - was dominantly driven by increased temperature. The variability in precipitation in the $\mathrm{A} 2$ climate scenario created a more variable BUI within the fire season as compared with base climate. The effect of altering precipitation was inconsequential in comparison to the effects of increasing temperature in determining both fuel flammability and availability. Details on precipitation effects on BUI are found in Table S9.

Climate driven increases in wildfire activity caused higher overall tree mortality and altered biomass accumulation rates. Simulated wildfires favored resprouting and fire-dependent aspen and chaparral shrubs, with details in Table S8 and Loudermilk et al. (2012).

\section{Discussion}

Our research highlights how past disturbance and future climate change may have multifaceted effects 

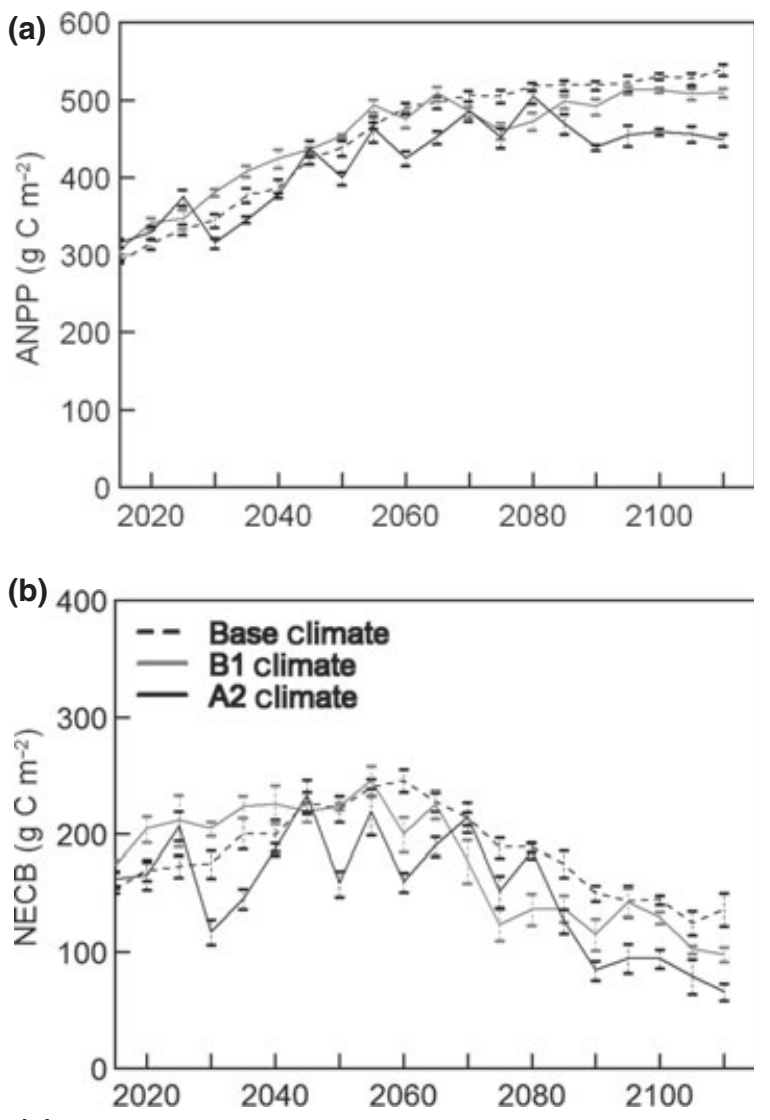

(c)

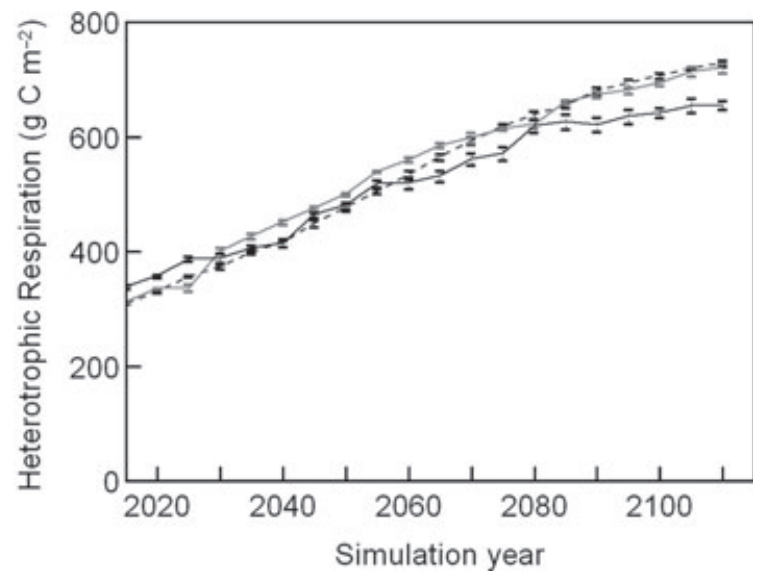

Fig. 6 Simulated mean landscape C estimates of (a) aboveground net primary productivity (ANPP), (b) net ecosystem carbon balance, and (c) heterotrophic respiration, simulated over 100 years (five replicates) and using contemporary (base) climate and two emissions scenarios (A2, B1). Note difference in scale of $y$-axis between graphs.

on a specific forested landscape (LTB). In particular, widespread and intense clearcut logging caused legacy effects, where forest growth will continue for a century or longer, and may offset the potential effects from climate change. Furthermore, climate-enhanced
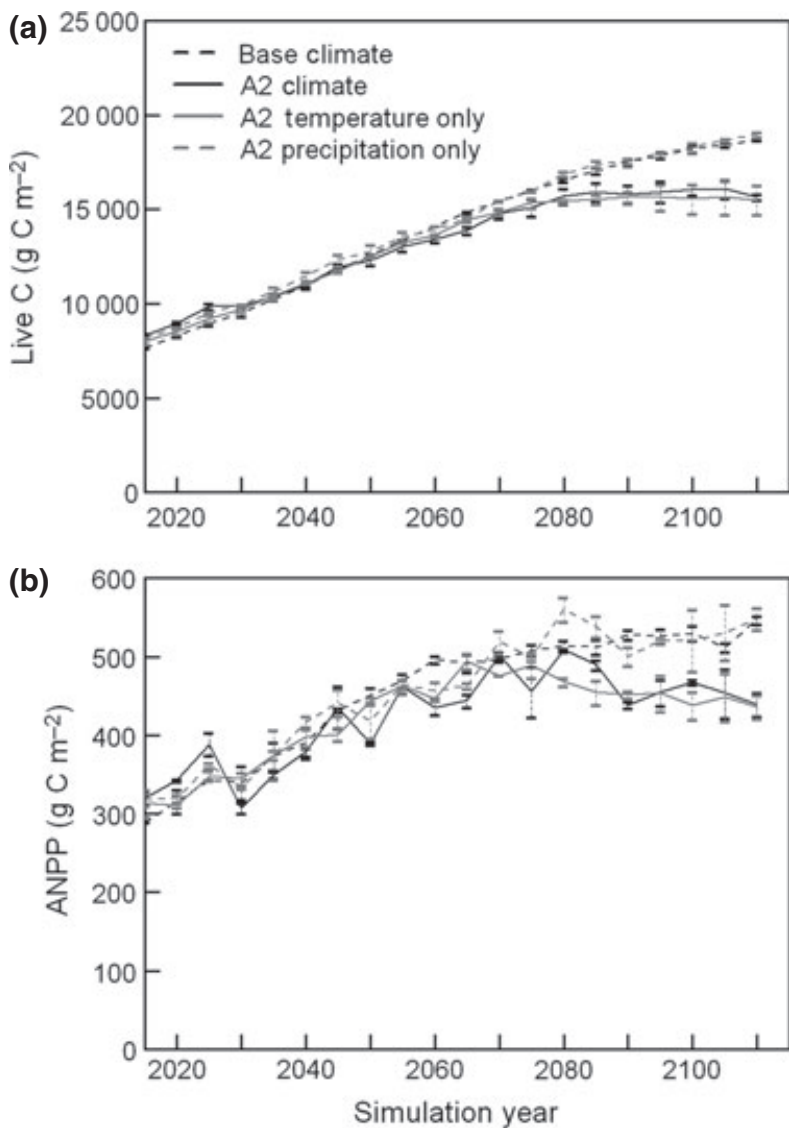

Fig. 7 Results from second simulation approach, where temperature and precipitation were independently assessed using the A2 and base climate. Increasing temperatures (as opposed to reduced precipitation) determined impacts on forest $C$ (a, live C) and productivity $[\mathrm{b}$, aboveground net primary productivity (ANPP)]. A2 Temperature only: A2 temperature combined with base climate precipitation; A2 Precipitation only: A2 precipitation combined with base climate temperature.

fire activity was more important for determining overall forest growth and $C$ storage potential than direct climate effects, such as changes in forest growth and establishment. The higher emissions climate scenario (A2 climate) had large effects on forest $\mathrm{C}$ and community dynamics, whereas the lower emissions scenario (B1 climate) had more subtle effects. The influence from climate change was primarily driven by temperature increases which affected wildfire activity, forest growth rates, heterotrophic respiration, mortality patterns, and tree establishment ability. Yearly fluctuations in precipitation influenced annual growth increment and C flux as well as within season fuel conditions, that, when coupled with higher temperatures, determined long-term forest productivity and $\mathrm{C}$ storage potential. 


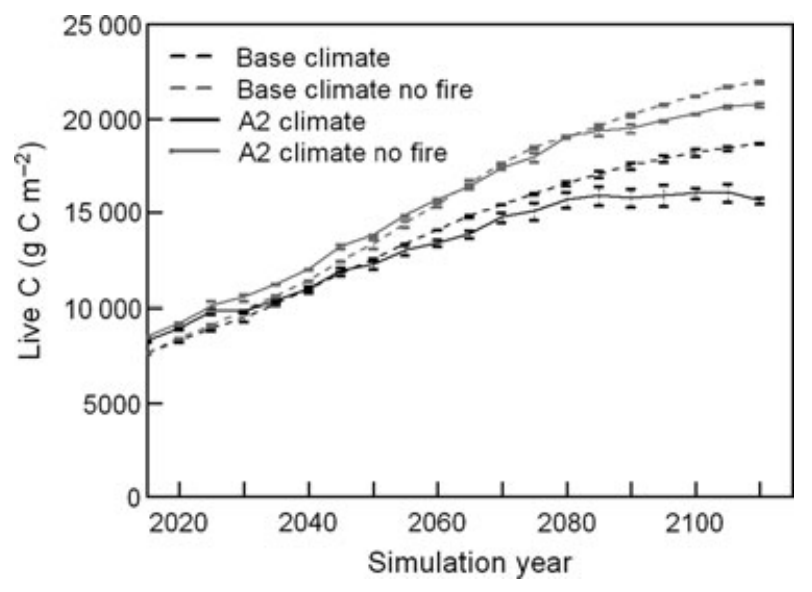

Fig. 8 Comparison of simulated live $\mathrm{C}$ with and without fire using the base and A2 climate scenarios.

\section{Climate change and landscape legacy effects on C dynamics}

Our study illustrated the potential for continued forest growth and sequestration of above and below ground C across the LTB, despite any potential shifts in climate into the coming decades. The forest continued to be a $\mathrm{C}$ sink (+NECB) where growth rates exceeded emissions from ecosystem respiration and wildfires. As the forest matures and reaches a more stable age structure, climate effects - both direct (e.g., loss of establishment, enhanced growth) and indirect (e.g., increased area burned) - may become more evident, especially if climate follows the more extreme predictions (e.g., GFDL A2 climate). The net $\mathrm{C}$ flow into the system was predicted to slow toward the end of the 21st century, at a faster rate for $\mathrm{A} 2$ than base climate. If wildfire occurrence surpasses our conservative estimates, this system would likely become a net C source $(-\mathrm{NECB})$ with increased C emissions (Meigs et al., 2011; North \& Hurteau, 2011).

The simulated C accumulation was quite large (50\% increase in 100 years) and was predominately a product of the legacy effect that the Comstock logging Era left on the landscape (60\% clearcut of LTB). After this abrupt logging event, the forest was left to regenerate. Most trees in the area are under 120 years old, well below their prospective age (Table 1, Dolanc et al., 2013) and potential biomass. The rate of growth into the next century suggests that the historic logging may have a greater effect on $\mathrm{C}$ storage than the potential effects of future changes in climate.

These legacy effects are evident across the world. A global analysis of C flux from 1850 to 2000 (Houghton, 2003a), illustrated that land use practices have been the driving mechanism of global $\mathrm{C}$ balance, and northern midlatitude regions (e.g., USA, Europe) have been transitioning to $C$ sinks toward the end of the 20th century from enhanced storage of $\mathrm{C}$ in forests. In WI, USA, only half of the forest $C$ has recovered since pre-Euro American settlement (1850s), and C storage may prolong as further fire suppression, forest in-growth, and forest recovery continues (Rhemtulla et al., 2009). In Europe, reforestation of abandoned areas in the European Alps has continued for over 150 years (Tasser et al., 2007). This extensive forest recovery may trump potential effects of climate change, at least into the coming decades. For example, extensive forest growth and recovery was projected in MA, USA over the next 50 years; regardless of changes in climate and land use patterns (Thompson et al., 2011), where reforestation has been prominent after centuries of extensive logging, settlement, and agriculture.

Despite the landscape legacy effects, our study illustrated how a varying climate may influence the rate of $\mathrm{C}$ sequestration into the coming century. The aboveground C pools were especially sensitive to the A2 climate, where enhanced mortality from fire and limited establishment of some species lowered $C$ storage potential (Fig. 5).

Soils of the LTB also sequestered C, regardless of climate regime, caused by a higher influx from the detrital to the SOC pools than outflux from soil respiration. Differences in landscape SOC among climate scenarios were less pronounced than those pools with more direct influence from disturbances (e.g., live C), and seen in other western studies (e.g., Smithwick et al., 2009). This was mainly because of the time lags associated with humification. In Sierra Nevada forests, soil C turnover may range from 7 to 65 years (Trumbore et al., 1996), suggesting the climate-driven processes and effects from varying inputs could span into the next century, beyond the timeline of this study. Despite this lag effect, there was a notable response of higher temperatures (A2 climate) lowering landscape-level heterotrophic respiration (Fig. 6c). Although stand-level effects from temperature on decomposition may be evident in nearby forests (e.g., Trumbore et al., 1996), this study suggests that local-scale effects may have little impact on the landscape SOC pool of the LTB into the near future. Understanding these soil processes and feedbacks with the aboveground environment are nonetheless important and should be included when studying climate's influence on soil respiration and overall $\mathrm{C}$ flux that may occur in the future (Conant et al., 2011).

The potential impact that temperature or drought may have on soil respiration (stimulation or suppression) may be overshadowed by the overall effect that changes in wildfire activity may have in determining 
the inputs (detrital C). In this study, wildfires suppressed SOC accumulation in all climate scenarios because much of the live and detrital $C$ that may have otherwise been incorporated into soil through humification was consumed during fire, similar to (Karam et al., 2013). The slow response of SOC to changes in detrital C, coupled with increased fire activity (less inputs), interacted in determining overall SOC, minimizing discrepancies between A2 and base climate (Fig. 4) until the last two decades. Unique to this study, SOC was not depleted due to increased soil respiration (as seen in Trumbore et al., 1996), although influence from reduced precipitation (suppressed respiration) may cause opposing feedbacks (Schindlbacher et al., 2012).

Climate change effects on forest growth rates and wildfire activity

Climate-enhanced wildfire activity reduced overall C sequestration potential, while species physiological response was mixed (Table S8). C fluctuations through time (Figs 5 and 6) were in response to annual changes in fire activity, postfire regeneration, as well as interannual variability in precipitation. These interacting feedbacks were reflected in the subtle differences in ANPP among the climate scenarios. For example, under the A2 climate, fire severity was higher, reducing ANPP, but subsequent regeneration and growth in these now 'open' spaces, boosted overall ANPP. ANPP was also affected by species level response. Subalpine and upper montane species experienced restricted recruitment ability after a $2^{\circ} \mathrm{C}$ increase in mean annual temperature, and others had periods of climate stimulated growth (Table S8).

The changing wildfire regime also altered forest successional trajectories. More wildfire activity in the A2 climate provided more areas for regeneration (and therefore more young cohorts) and more shrub cover (due to resprouting after fire) across the basin (Loudermilk et al., 2012). These fire-driven changes in fuel characteristics and community structure, e.g., shrub dominance, have been found historically in the Basin (Nagel \& Taylor, 2005) and in other western landscapes (Westerling et al., 2011). This suggests that climateenhanced fire activity may alter forest composition and structure more than any direct forest response to climate. In addition, the response of fire activity to changes in climate is ultimately faster than the effects of climate on species or community response (Dale et al., 2001).

Higher summer temperatures during a longer growing season created a more ideal climate-fire environment. Fine fuel moisture content was lower throughout the fire season (earlier snow melt in the spring, as seen in Westerling et al., 2006), and ignition and fire spread potential increased into the coming century. Although wildfires in the LTB are currently of high intensity and cause moderate to high severity in unmanaged areas (85-100\% mortality; Safford et al., 2009), annual area burned remains small compared to historic conditions (Beaty \& Taylor, 2008) and Western wildfires (Westerling et al., 2006; Littell et al., 2009). An extended fire season, coupled with drier conditions, may significantly increase area burned, as seen in this study. This is especially true given current stand conditions that promote more damaging wildfires, such as high surface fuel loads and high densities of younger trees (ladder fuels) and snags (Agee \& Skinner, 2005). Similar effects of changing climate-fire dynamics have been found throughout western forests, including the Sierra Nevada (Littell et al., 2009), as well as in boreal systems (Girardin et al., 2010), south African systems (Archibald et al., 2009), and projected globally (Gonzalez et al., 2010).

Although more wildfires in a changing climate reduced $C$ sequestration potential, these are most likely moderate estimates because of the conservative nature of the simulated fire regime. For instance, the historic LTB fire regime, reconstructed from fire scars (ca. 1700 1880), had more frequent low-severity fires and was substantially different from the postlogging (ca. 1880 2000) regime (Beaty \& Taylor, 2008). For our study, we calibrated our model using data from 1995 to 2007, which included small, infrequent, and often deliberately suppressed wildfires. With the current state of fuel conditions (e.g., high density of younger cohorts) and altered ignition patterns (e.g., primarily human caused; Safford et al., 2009; and see Loudermilk et al., 2012), increased fire activity is highly probable, notwithstanding climate change effects. This emphasizes the importance of understanding how subtle regional changes in temperature and precipitation influence fire weather, fuel conditions, and changes in fire season, which may impact systems globally (Archibald et al., 2009).

Many ecosystem processes (e.g., C cycling, fire disturbance, forest succession) that were included in this study interact in unique ways within a forested landscape. Inclusion of additional relevant processes (e.g., drought stress, and insect and disease outbreaks; Adams et al., 2009), sudden ecosystem events (e.g., drought-induced die-back events; Allen et al., 2010) and global change factors (e.g., increasing $\mathrm{CO}_{2}$ concentrations, $\mathrm{N}$ deposition rates, and fire ignitions) may result in unanticipated ecosystem dynamics (Westerling et al., 2006; Syphard et al., 2007). Forest management practices and human land use affect $\mathrm{C}$ dynamics 
as well. For example, fuel reduction treatments scheduled for the LTB (Marlow et al., 2007) may affect wildfire spread and severity (Safford et al., 2009), and alter live $\mathrm{C}$ sequestration potential in the long run (North \& Hurteau, 2011; Campbell et al., 2012). The continuous application of fuel treatments may be especially important if natural and anthropogenic ignition sources increase as projected in the LTB (Loudermilk et al., 2012).

Influences from climate change, coupled with these biotic and abiotic disturbances, may accelerate the transition to a $\mathrm{C}$ emitting or $\mathrm{C}$ neutral system (Kurz et al., 1995; Adams et al., 2009). Other C pools, such as charcoal formation (DeLuca \& Aplet, 2008; Karam et al., 2013), may be incorporated. Comparative phenology studies, which focus on effects from a longer growing season (Gunderson et al., 2012; Jeong et al., 2011), may also be important to consider in future studies.

In summary, this research illustrated the influence of multiple landscape-level processes that interact over large spatial and temporal scales to drive forest C dynamics. Our modeling approach provided an avenue to analyze the emergent outcomes of interactions among climate, wildfire, forest succession, and nutrient cycling among above and belowground nutrient pools. The influence of climate on fire weather and resulting fire activity was substantial and emphasizes the need to incorporate these processes when addressing questions about climate change effects on forested landscapes. Although the response of individual species to climate change may be unique within forested regions, the effects of past and future disturbances on overall landscape dynamics may be more influential and widespread in driving long-term forest $\mathrm{C}$ balance. In conclusion, the future of forest ecosystem C cycling in many forested systems worldwide may depend more on landscape legacies related to land use or major disturbances than on projected climate change alone.

\section{Acknowledgments}

Funding was provided by the Southern Nevada Public Land Management Act, Bureau of Lands Management. The downscaled projected climate data were provided by Bob Coats and associates, University of California-Davis. We thank the USDA Forest Service, especially the Pacific Southwest Research Station for their support, specifically Jonathan Long and Tiffany van Huysen. Researchers, and managers of the Lake Tahoe Basin have been integral to this project, providing feedback at local workshops and meetings. We thank Portland State University (PSU) and University of Nevada-Reno for their administrative support. The research team of the Dynamic Ecosystems and Landscapes Lab at PSU was especially important for the success of this project.

\section{References}

Adams HD, Guardiola-Claramonte M, Barron-Gafford GA et al. (2009) Temperature sensitivity of drought-induced tree mortality portends increased regional die-off under global-change-type drought. Proceedings of the National Academy of Sciences, 106, 7063-7066.

Agee JK, Skinner CN (2005) Basic principles of forest fuel reduction treatments. Forest Ecology and Management, 211, 83-96.

Albani M, Medvigy D, Hurtt GC, Moorcroft PR (2006) The contributions of land-use change, $\mathrm{CO}_{2}$ fertilization, and climate variability to the Eastern US carbon sink. Global Change Biology, 12, 2370-2390.

Allen CD, Macalady AK, Chenchouni $\mathrm{H}$ et al. (2010) A global overview of drought and heat-induced tree mortality reveals emerging climate change risks for forests. Forest Ecology and Management, 259, 660-684.

Archibald S, Roy DP, Van Wilgen BW, Scholes RJ (2009) What limits fire? An examination of drivers of burnt area in Southern Africa. Global Change Biology, 15, 613-630.

Barbour M, Kelley E, Maloney P, Rizzo D, Royce E, Fites-Kaufmann J (2002) Present and past Old-Growth Forests of the Lake Tahoe Basin, Sierra Nevada, US. Journal of Vegetation Science, 13, 461-472.

Battles J, Robards T, Das A, Waring K, Gilless J, Biging G, Schurr F (2008) Climate change impacts on forest growth and tree mortality: a data-driven modeling study in the mixed-conifer forest of the Sierra Nevada, California. Climatic Change, 87, 193-213.

Beaty RM, Taylor AH (2008) Fire history and the structure and dynamics of a mixed conifer forest landscape in the northern Sierra Nevada, Lake Tahoe Basin, California, USA. Forest Ecology and Management, 255, 707-719.

Campbell J, Donato D, Azuma D, Law B (2007) Pyrogenic carbon emission from a large wildfire in Oregon, United States. Journal of Geophysical Research, 112, $1-11$.

Campbell J, Alberti G, Martin J, Law BE (2009) Carbon dynamics of a ponderosa pine plantation following a thinning treatment in the northern Sierra Nevada. Forest Ecology and Management, 257, 453-463.

Campbell J, Harmon ME, Mitchell SR (2012) Can fuel-reduction treatments really increase forest carbon storage in the western US by reducing future fire emissions? Frontiers in Ecology and the Environment, 10, 83-90.

Cantarello E, Newton AC, Hill RA et al. (2011) Simulating the potential for ecological restoration of dryland forests in Mexico under different disturbance regimes. Ecological Modelling, 222, 1112-1128.

Chapin FS, Matson PA, Mooney HA (eds) (2002) Terrestrial Production Processes. In: Principles of Terrestrial Ecosystem Processes, pp. 123-150. Springer-Verlag New York, Inc., New York, NY

Coats R, Reuter J, Dettinger M et al. (2010) Final Report: The Effects of Climate Change on Lake Tahoe in the 21st Century: Meteorology, Hydrology, Loading and Lake Response. Pacific Southwest Research Station, Tahoe Center for Environmental Studies, Incline Village, $\mathrm{NV}$

Conant RT, Ryan MG, Ågren GI et al. (2011) Temperature and soil organic matter decomposition rates - synthesis of current knowledge and a way forward. Global Change Biology, 17, 3392-3404.

Critchfield WB, Little EL Jr (1966) Geographic Distribution of the Pines of the World. US Department of Agriculture, Washington, DC

Dale VH, Joyce LA, McNulty S et al. (2001) Climate change and forest disturbances. BioScience, 51, 723-734

DeLuca TH, Aplet GH (2008) Charcoal and carbon storage in forest soils of the Rocky Mountain West. Frontiers in Ecology and the Environment, 6, 18-24.

Dobrowski S, Greenberg J, Ustin S (2005) Tahoe Basin existing vegetation map v. 4.1 Ecological Modelling, 192, 126-142.

Dolanc CR, Thorne JH, Safford HD (2013) Widespread shifts in the demographic structure of subalpine forests in the Sierra Nevada, California, 1934 to 2007. Global Ecology and Biogeography, 22, 264-276.

Galik CS, Jackson RB (2009) Risks to forest carbon offset projects in a changing climate. Forest Ecology and Management, 257, 2209-2216.

Girardin MP, Ali AA, Hély C (2010) Wildfires in boreal ecosystems: past, present and some emerging trends. International Journal of Wildland Fire, 19, 991-995.

Gonzalez P, Neilson RP, Lenihan JM, Drapek RJ (2010) Global patterns in the vulnerability of ecosystems to vegetation shifts due to climate change. Global Ecology $\mathcal{E}$ Biogeography, 19, 755-768.

Goodale CL, Apps MJ, Birdsey RA et al. (2002) Forest carbon sinks in the Northern Hemisphere. Ecological Applications, 12, 891-899.

Gunderson CA, Edwards NT, Walker AV, O'hara KH, Campion CM, Hanson PJ (2012) Forest phenology and a warmer climate - Growing season extension in relation to climatic provenance. Global Change Biology, 18, 2008-2025. 
Higgins SI, Richardson DM, Cowling RM (2001) Validation of a spatial simulation model of a spreading alien plant population. Journal of Applied Ecology, 38, 571-584.

Houghton RA (2003a) Revised estimates of the annual net flux of carbon to the atmosphere from changes in land use and land management 1850-2000. Tellus B, 55, 378-390.

Houghton RA (2003b) Why are estimates of the terrestrial carbon balance so different? Global Change Biology, 9, 500-509.

Jeong S-J, Ho C-H, Gim H-J, Brown ME (2011) Phenology shifts at start vs. end of growing season in temperate vegetation over the Northern Hemisphere for the period 1982-2008. Global Change Biology, 17, 2385-2399.

Karam SL, Weisberg PJ, Scheller RM, Johnson DW, Miller W (2013) Development and evaluation of a nutrient cycling extension for the LANDIS-II landscape simulation model. Ecological Modelling, 250, 45-57.

Kirschbaum MUF (1995) The temperature dependence of soil organic matter decomposition, and the effect of global warming on soil organic C storage. Soil Biology and Biochemistry, 27, 753-760.

Kurz WA, Apps MJ, Beukema SJ, Lekstrum T (1995) 20th century carbon budget of Canadian forests. Tellus B, 47, 170-177.

Lenihan JM, Drapek R, Bachelet D, Neilson RP (2003) Climate change effects on vegetation distribution, carbon, and fire in California. Ecological Applications, 13, $1667-$ 1681.

Littell JS, McKenzie D, Peterson DL, Westerling AL (2009) Climate and wildfire area burned in western U.S. ecoprovinces, 1916-2003. Ecological Applications, 19, 1003 1021.

Loudermilk EL, Stanton AE, Scheller RM, Weisberg PJ, Yang J, Dilts TE, Skinner C (2012) Final Report: Management Options for Reducing Wildfire Risk and Maximizing Carbon Storage under Future Climate Changes, Ignition Patterns, and Forest Treatments. Pacific Southwest Research Station, Tahoe Center for Environmental Studies, Incline Village, NV

Marlow D, French C, Graham W et al. (2007) Lake Tahoe Basin: Multi-Jurisdictional Fuel Reduction and Wildfire Prevention Strategy 10 Year Plan. Lake Thaoe Basin Management Unit, South Lake Tahoe, CA.

McKenzie D, Gedalof ZE, Peterson DL, Mote P (2004) Climatic change, wildfire, and conservation. Conservation Biology, 18, 890-902.

Meigs G, Turner D, Ritts W, Yang Z, Law B (2011) Landscape-scale simulation of heterogeneous fire effects on pyrogenic carbon emissions, tree mortality, and net ecosystem production. Ecosystems, 14, 758-775.

Millar CI, Neilson D, Batchelet R, Drapek R, Lenihan JM (2006) Climate change at multiple scales. In: Forests, Carbon, and Climate Change: A Synthesis of Science Findings (eds Salwasser H, Cloughesy M), pp. 31-62. Oregon Forest Resources Institute, Portland, OR.

Millar CI, Stephenson NL, Stephens SL (2007) Climate change and forests of the future: managing in the face of uncertainty. Ecological Applications, 17, 2145-2151.

Miller WW, Johnson DW, Karam SL, Walker RF, Weisberg PJ (2010) A Synthesis of Sierran Forest Biomass Management Studies and Potential Effects on Water Quality. Forests, 1, 131-153.

Nagel TA, Taylor AH (2005) Fire and persistence of montane chaparral in mixed conifer forest landscapes in the Northern Sierra Nevada, Lake Tahoe Basin, California, USA. Journal of the Torrey Botanical Society, 132, 442-457.

North MP, Hurteau MD (2011) High-severity wildfire effects on carbon stocks and emissions in fuels treated and untreated forest. Forest Ecology and Management, 261 1115-1120.

Ottmar R, Safford H (2011) Final Report: FCCS Fuelbeds for the Lake Tahoe Basin Management Unit. Pacific Southwest Research Station, Tahoe Center for Environmental Studies, Incline Village, NV.

Parton WJ, Anderson DW, Cole CV, Stewart JWB (1983) Simulation of soil organic matter formation and mineralization in semiarid agroecosystems. In: Nutrien Cycling in Agricultural Ecosystems (eds Lowrance RR, Todd RL, Asmussen LE, Leonard RA), pp. 533-550. The University of Georgia, College of Agriculture Experimental Stations, Athens, Georgia.

Parton WJ, Schimel D, Ojima D, Cole CV, Bryant R, Arnold R (1994) A general model for soil organic matter dynamics: sensitivity to litter chemistry, texture and management. In: Quantitative Modeling of Soil Forming Processes: Proceedings of a Symposium Sponsored by Divisions S-5 and S-9 of the Soil Science Society of America in Minneapolis, Minnesota, USA, 2 Nov. 1992 (ed. Bryant RB, Arnold RW), pp. 147-167, Soil Science Society of America Inc., Madison, Wisconsin.

Rhemtulla JM, Mladenoff DJ, Clayton MK (2009) Historical forest baselines reveal potential for continued carbon sequestration. Proceedings of the National Academy of Sciences, 106, 6082-6087.
Rogers JH (1974) Soil Survey Tahoe Basin Area: California and Nevada. US Department of Agriculture, Soil Conservation Service, Washington, DC.

Running SW (2006) Is global warming causing more, larger wildfires? Science, 313, 927-928.

Safford HD, Schmidt DA, Carlson CH (2009) Effects of fuel treatments on fire severity in an area of wildland-urban interface, Angora Fire, Lake Tahoe Basin, California. Forest Ecology and Management, 258, 773-787.

Schäfer KVR, Oren R, Ellsworth DS, et al. (2003) Exposure to an enriched $\mathrm{CO}_{2}$ atmosphere alters carbon assimilation and allocation in a pine forest ecosystem. Global Change Biology, 9, 1378-1400.

Scheller RM, Mladenoff DJ (2005) A spatially interactive simulation of climate change, harvesting, wind, and tree species migration and projected changes to forest composition and biomass in northern Wisconsin, USA. Global Change Biology, 11, 307-321.

Scheller R, Mladenoff D (2008) Simulated effects of climate change, fragmentation, and inter-specific competition on tree species migration in northern Wisconsin, USA. Climate Research, 36, 191-202.

Scheller RM, Domingo JB, Sturtevant BR, Williams JS, Rudy A, Gustafson EJ, Mladenoff DJ (2007) Design, development, and application of LANDIS-II, a spatial landscape simulation model with flexible temporal and spatial resolution. Ecological Modelling, 201, 409-419.

Scheller RM, Hua D, Bolstad PV, Birdsey RA, Mladenoff DJ (2011a) The effects of forest harvest intensity in combination with wind disturbance on carbon dynamics in Lake States Mesic Forests. Ecological Modelling, 222, 144-153.

Scheller RM, Van Tuyl S, Clark K, Hom J, La Puma I (2011b) Carbon Sequestration in the New Jersey Pine Barrens Under Different Scenarios of Fire Management. Ecosystems, 14, 987-1004.

Schindlbacher A, Wunderlich S, Borken W, Kitzler B, Zechmeister-Boltenstern S, Jandl R (2012) Soil respiration under climate change: prolonged summer drought offsets soil warming effects. Global Change Biology, 18, 2270-2279.

Smithwick E, Ryan M, Kashian D, Romme W, Tinker D, Turner M (2009) Modeling the effects of fire and climate change on carbon and nitrogen storage in lodgepole pine (Pinus contorta) stands. Global Change Biology, 15, 535-548.

Steenberg JWN, Duinker PN, Bush PG (2011) Exploring adaptation to climate change in the forests of central Nova Scotia, Canada. Forest Ecology and Management, 262, 2316-2327.

Sturtevant BR, Scheller RM, Miranda BR, Shinneman D, Syphard A (2009) Simulating dynamic and mixed-severity fire regimes: a process-based fire extension for LAN DIS-II. Ecolooical Modelling, 220, 3380-3393.

Syphard AD, Radeloff VC, Keeley JE, Hawbaker TJ, Clayton MK, Stewart SI, Hammer RB (2007) Human influence on California fire regimes. Ecological Applications, 17, 1388-1402.

Syphard AD, Scheller RM, Ward BC, Spencer WD, Strittholt JR (2011) Simulating landscape-scale effects of fuels treatments in the Sierra Nevada, California, USA. International Journal of Wildland Fire, 20, 364-383.

Tasser E, Walde J, Tappeiner U, Teutsch A, Noggler W (2007) Land-use changes and natural reforestation in the Eastern Central Alps. Agriculture, Ecosystems \& Environment, 118, 115-129.

Thompson JR, Foster DR, Scheller RM, Kittredge D (2011) The influence of land use and climate change on forest biomass and composition in Massachusetts, USA Ecological Applications, 21, 2425-2444.

Trumbore SE, Chadwick OA, Amundson R (1996) Rapid exchange between soil carbon and atmospheric carbon dioxide driven by temperature change. Science, 272, 393-396.

Van Mantgem PJ, Stephenson NL, Byrne JC et al. (2009) Widespread increase of tree mortality rates in the Western United States. Science, 323, 521-524.

Van Wagner CE (1987) Development and structure of the Canadian Forest Fire Weather Index System. Forestry Technical Report 35, Canadian Forestry Service, Headquarters, Ottawa.

Westerling AL, Hidalgo HG, Cayan DR, Swetnam TW (2006) Warming and earlier spring increase Western US. Forest Wildfire Activity. Science, 313, 940-943.

Westerling AL, Turner MG, Smithwick EA, Romme WH, Ryan MG (2011) Continued warming could transform Greater Yellowstone fire regimes by mid-21st century. Proceedings of the National Academy of Sciences, 108, 13165-13170.

$\mathrm{Xu}$ C, Gertner GZ, Scheller RM (2007) Potential effects of interaction between $\mathrm{CO}_{2}$ and temperature on forest landscape response to global warming. Global Change Biology, 13, 1469-1483.

Xu C, Gertner GZ, Scheller RM (2009) Uncertainties in the response of a forest landscape to global climatic change. Global Change Biology, 15, 116-131. 


\section{Supporting Information}

Additional Supporting Information may be found in the online version of this article:

Figure S1. Growth response to temperature.

Figure S2. Range of soil organic matter decay rates.

Figure S3. Output fire summary graph and statistics.

Table S1. Century extension input parameters.

Table S2. Functional type parameters for the species list in Table 1.

Table S3. Initial values of carbon and nitrogen in various soil organic pools.

Table S4. Ecoregion fixed parameters.

Table S5. References for input parameters to the century extension.

Table S6. Fire regime parameter inputs for the dynamic fire extension.

Table S7. Response of $\mathrm{C}$ dynamics to climate change.

Table S8. Individual species response to climate change.

Table S9. More details on precipitation effects on Build-Up Index. 